\title{
Morphometric bone assessment of men and women in different age range by cone
}

\section{beam computerized tomography}

\author{
Avaliação óssea morfométrica de homens e mulheres em diferentes faixas etárias pela tomografia \\ computadorizada de feixe cônico
}

Evaluación ósea morfométrica de hombres y mujeres en diferentes gama de edades mediante

tomografía computerizada de haz cónico

Received: 06/02/2021 | Reviewed: 06/09/2021 | Accept: 08/03/2021 | Published: 08/08/2021

Kelmara Arruda Pinho

ORCID: https://orcid.org/0000-0002-8598-7945

São Leopoldo Mandic College, Brazil

E-mail: pinho.kelmara@gmail.com

Paola Fernanda Leal Corazza

ORCID: https://orcid.org/0000-0002-8639-8392 APCD College of Dentistry, Brazil

E-mail: paola_corazza@hotmail.com

Fernando Martins Baeder

ORCID: https://orcid.org/0000-0001-7101-5689

Cruzeiro do Sul University, Brazil

E-mail: fernandobaeder@uol.com.br

Daniel Furtado Silva

ORCID: https://orcid.org/0000-0003-3319-2996 Federal University of Paraíba, Brazil

E-mail: furtado.ds@gmail.com

Ana Carolina Lyra de Albuquerque

ORCID: https://orcid.org/0000-0002-6532-5020 Federal University of Paraíba, Brazil E-mail: lina.lyra@gmail.com

Luiz Roberto Coutinho Manhães Júnior ORCID: https://orcid.org/0000-0003-1642-5241 São Leopoldo Mandic College, Brazil E-mail: 1rmradio@yahoo.com

José Luiz Cintra Junqueira

ORCID: https://orcid.org/0000-0001-6788-4021 São Leopoldo Mandic College, Brazil

E-mail: joseluiz@slmandic.edu.br

Francine Kühl Panzarella

ORCID: https://orcid.org/0000-0002-5650-7711

São Leopoldo Mandic College, Brazil

E-mail: francine.panzarella@gmail.com

\begin{abstract}
Osteoporosis corresponds to a decrease in bone mass and micro-architectural deterioration of bone tissue, causing bone fragility and risk of fractures. Although osteoporosis is four times more common in women than in men, they tend to have more complications with a higher risk of mortality after hip fracture. The silent nature of osteoporosis causes delays in early diagnosis, compromising adequate treatment. The objective was to evaluate bone morphometry and correlate morphometric indices between men and women, and between women of different age groups. The sample was divided into: men aged 65 to 75 years (A); women from 45 to 55 years (B1); women from 56 to 65 years (B2) and women from 66 to 75 years (B3). The morphometric indices Computed Tomography Cortical Index (CTCI), the Computerized Tomography Mental Index (MI), the Upper Mandibular Computerized Tomography Index (MCTI$\mathrm{U}$ ) and the Lower Mandibular Computed Tomography Index (MCTI-L) were analyzed by through the OnDemand3D software. There were significant differences between the different groups in MI, MCTI-L and MCTI-U and a high correlation between the indices. There was no difference in CTCI when used alone. There are differences in the bone structure of men and women, and between women of different age groups, and the quantitative and qualitative indices can be a useful tool in detecting patients with low bone density when used together for subsequent referral for bone densitometry and specialized medical treatment.
\end{abstract}

Keywords: Bone density; Cone beam computed tomography; Anatomy; Diagnosis. 


\begin{abstract}
Resumo
A osteoporose corresponde à diminuição da massa óssea e deterioração micro-arquitetural do tecido ósseo, provocando fragilidade óssea e risco de fraturas. Apesar de a osteoporose ser quatro vezes mais comum em mulheres do que em homens, estes tendem a ter mais complicações com risco maior de mortalidade após fratura de quadril. A natureza silenciosa da osteoporose causa atrasos no diagnóstico precoce comprometendo um tratamento adequado. $\mathrm{O}$ objetivo foi avaliar a morfometria óssea e correlacionar os índices morfométricos entre homens e mulheres, e entre mulheres de diferentes faixas etárias. A amostra foi dividida em: homens de 65 a 75 anos (A); mulheres de 45 a 55 anos (B1); mulheres de 56 a 65 anos (B2) e mulheres de 66 a 75 anos (B3). Os índices morfométricos Índice Cortical da Tomografia Computadorizada (ICTC), o Índice Mentual de Tomografia Computadorizada (IM), o Índice de Tomografia Computadorizada Mandibular Superior (ITCM-S) e o Índice de Tomografia Computadorizada Mandibular Inferior (ITCM-I) foram analisados por meio do software OnDemand3D. Houve diferenças significativas entre os diferentes grupos no IM, ITCM-I e ITCM-S e alta correlação entre os índices. Não houve diferença no ICTC quando utilizado de forma isolada. Há diferenças na estrutura óssea de homens e mulheres, e entre mulheres de diferentes faixas etárias, e os Índices quantitativos e qualitativos podem ser uma ferramenta útil na detecção de pacientes com baixa densidade óssea quando utilizados em conjunto para o posterior encaminhamento para densitometria óssea e tratamento médico especializado.
\end{abstract}

Palavras-chave: Densidade óssea; Tomografia computadorizada de feixe cônico; Anatomia; Diagnóstico.

\title{
Resumen
}

La osteoporosis corresponde a la disminución de la masa ósea y deterioro de la microarquitectura del tejido óseo, lo que provoca fragilidad ósea y riesgo de fracturas. Aunque la osteoporosis es cuatro veces más común en mujeres que en hombres, tienden a tener más complicaciones con un mayor riesgo de mortalidad después de una fractura de cadera. La naturaleza silenciosa de la osteoporosis provoca retrasos en el diagnóstico precoz, comprometiendo un tratamiento adecuado. El objetivo fue evaluar la morfometría ósea y correlacionar índices morfométricos entre hombres y mujeres, entre mujeres de diferentes grupos de edad. La muestra se dividió en: hombres de 65 a 75 años (A); mujeres de 45 a 55 años (B1); mujeres de 56 a 65 años (B2) y mujeres de 66 a 75 años (B3). Los índices morfométricos Índice Cortical de Tomografía Computarizada (ICTC), Índice Mental de Tomografía Computarizada (IM), Índice de Tomografía Computarizada Mandibular Superior (ITCM-S) y el Índice de Tomografía Computarizada Mandibular Inferior (ITCM-I) fueron analizados por a través del software OnDemand3D. Hubo diferencias significativas entre los diferentes grupos en IM, ITCM-I e ITCM-S y una alta correlación entre los índices. No hubo diferencias en ICTC cuando se usó solo. Existen diferencias en la estructura ósea de hombres y mujeres, y entre mujeres de diferentes grupos de edad, y los índices cuantitativos y cualitativos pueden ser una herramienta útil en la detección de pacientes con baja densidad ósea cuando se utilizan juntos para su posterior derivación para densitometría ósea y tratamiento médico especializado.

Palabras clave: Densidad ósea; Tomografía computarizada de haz cónico; Anatomía; Diagnóstico.

\section{Introduction}

Osteoporosis is defined as a systemic skeletal disease with decreased bone mass and micro-architectural deterioration of bone tissue, resulting in bone fragility and an increased risk of osteoporotic fracture, especially in the regions of the hip and vertebrae. It is considered a worldwide public health problem and is associated with a high rate of mortality and morbidity (Brasileiro et al., 2017, Shokri et al., 2019; Taguchi et al., 2020; Yousefi et al., 2021), with financial and psychosocial consequences for the individual, family and society (Aziziyeh et al., 2019).

Although osteoporosis is four times more common in women than in men, some evidence indicates that men tend to have more complications with a higher risk of mortality after hip fracture (Adler, 2014; Alswat, 2017). The silent nature of osteoporosis causes delays in early diagnosis, compromising proper treatment (Syed \& Ng, 2010).

For osteoporosis diagnosis, techniques such as quantitative ultrasonography, quantitative computed tomography, dual energy X-ray absorptiometry and peripheral dual energy X-ray absorptiometry are available (Ito, 2011).

Cone beam computed tomography (CBCT) is an image exam with several clinical applications widely used in dentistry (Corazza et al., 2020; Marques et al., 2021; Pêgo et al., 2021) that provides a three-dimensional representation of the maxillofacial region with minimal distortion, image clarity, low cost and low radiation dose compared to other modalities of computed tomography, in addition to allow a qualitative and quantitative assessment of bone structures (Mostafa, Arnout \& Abo El-Fotouh, 2016). It should be noted that the high visibility of the lower mandibular cortex in this imaging modality, 
favors the application of morphometric indices in all its extension through a dynamic evaluation (Alonso et al., 2016), indicating CBCT as an adjuvant diagnostic tool to refer patients at risk of osteoporosis to densitometric analysis. (Geibel, Löffler \& Kildal, 2016; Guerra et al., 2017).

Morphometric indices and radiographic density derived from CBCT should be promising tools for screening individuals with low bone mineral density (BMD) and be a preliminary tool in the diagnosis of osteoporosis (Güngör, Yildirim \& Çevik, 2016; Mostafa, Arnout \& Abo El-Fotouh, 2016; Guerra et al., 2017). Additionally, it has been reported that BMD in the mental foramen region has been related to BMD in the lumbar spine of postmenopausal women using quantitative computed tomography (QCT) techniques (Brasileiro et al., 2017).

To understand the influence of sex and age on bone morphometry, the present study applied morphometric indices in tomographic examinations of men and women, and also among women of different age groups, and correlated them to verify for differences in bone structure.

\section{Methodology}

CBCT exams performed at the radiology clinic of Faculdade São Leopoldo Mandic were selected according to the inclusion criteria: CBCT that includes the mandible, examinations of women aged 45 to 75 years and men aged 65 to 75 years. Examinations of patients with bone malformation or with lesions in the region of interest, or tests of low quality were excluded.

All examinations were performed using a conical beam volumetric acquisition device (OP 300 maxio, Istrumentarium dental, type BLD-NGEO-M, serie $n^{\circ}$ IE1503469B. Tuusula, Finlândia) and the assessment was performed by a single examiner. The sample obtained for convenience was composed of all CBCT performed in a one-year period that was in accordance with the eligibility criteria, resulting in a sample of 147 CBCTs. The exams were separated according to sex and age group: men aged 65 to 75 years (A), women aged 45 to 55 years (B1), women aged 56 to 65 years (B2) and women aged 66 to 75 years (B3).

The images were examined using the 17" flat-screen LCD monitor, monitor model 5000: 1 (LG, Seoul, Korea), with a resolution of 1280 x 1024 pixels and maximum color quality (12 bits) in a low light environment.

Using the tomograph's software, OnDemand3D, after the multiplanar reformatting, a qualitative assessment was performed in the panoramic reconstruction and classified according to the Computed Tomography Cortical Index (CTCI) that assesses the degree of resorption of the lower cortex of the base of the mandible in : clear and sharp cortical margin on both sides (C1); endosteal surface with semilunar defects (lacunar resorption) or surface showing cortical residues (C2); extremely porous cortical layer (C3), as shown in figure 1 (Koh \& Kim, 2011).

The images of the axial and coronal planes of the mandible were always positioned in the same location to identify the most central region of the mental foramen. The images of the axial and coronal planes of the mandible were always positioned in the same location to identify the most central region of the mental foramen. The data were compiled in an Excel spreadsheet (Microsoft, USA), from the measurements taken in the coronal section according to the morphometric indices (Figura 2):

I.Computed Tomography Mental Index (MI): measured thickness of the mandibular cortical bone in the region of the mental foramen (Figure 2A).

II.Upper Mandibular Computerized Tomography Index (MCTI-U) ratio of the thickness of the lower cortex to the distance from the upper margin of the mental foramen to the lower edge of the mandible. (Figure 2B).

III.Lower Mandibular Computerized Tomography Index (MCTI-L): ratio of the thickness of the lower cortex to the distance from the lower margin of the mental foramen to the lower edge of the mandible (Figure 2C). 
Figure 1. Panoramic reconstruction of the CTCI classification with a thickness of $15 \mathrm{~mm}$.

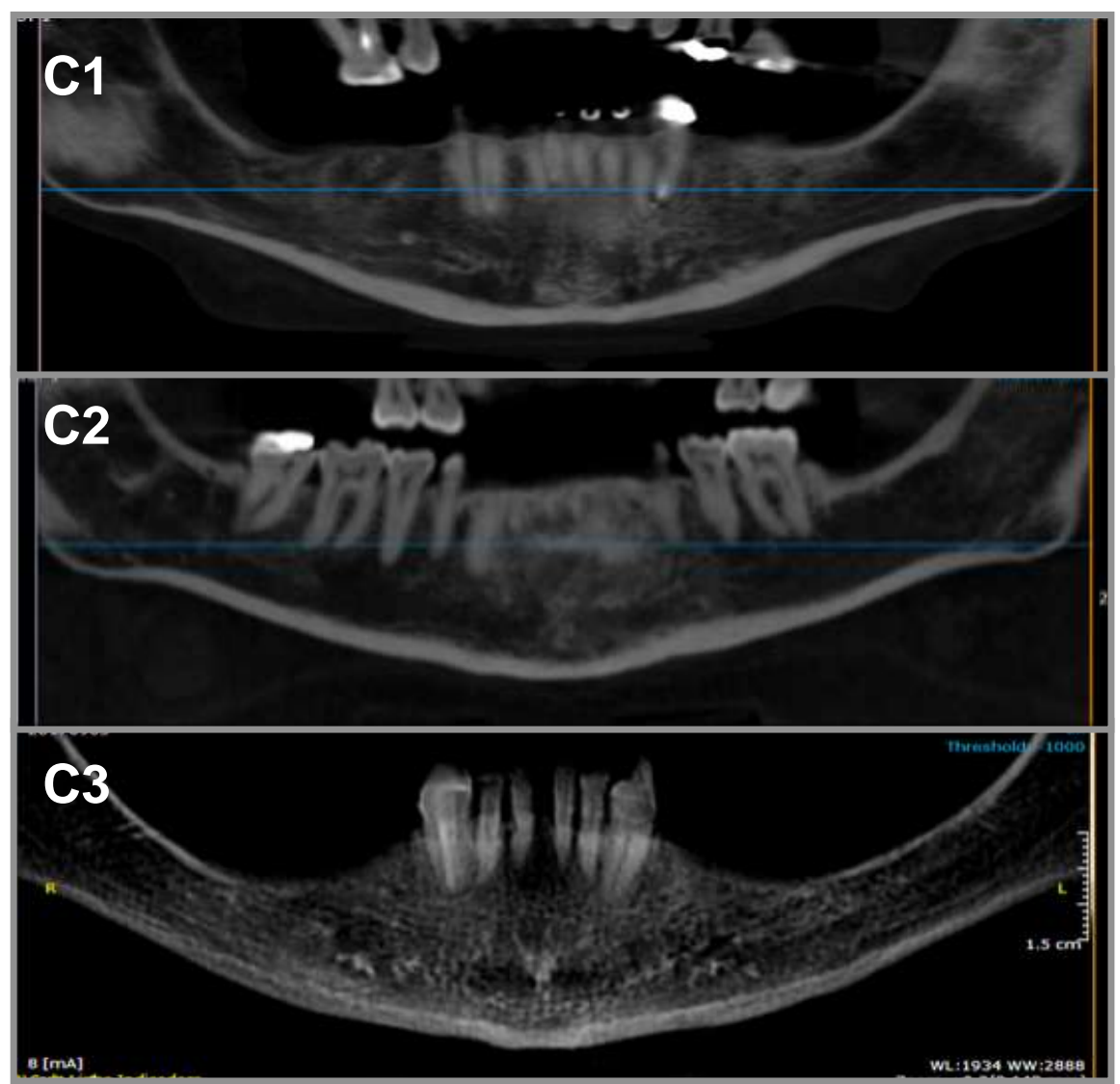

Own authorship.

Figure 2. Morphometric indices: (A) Computed Tomography Mental Index (MI); (B) Upper Mandibular Computed Tomography Index (MCTI-U); (C) Lower Mandibular Index of Computed Tomography (MCTI-L).

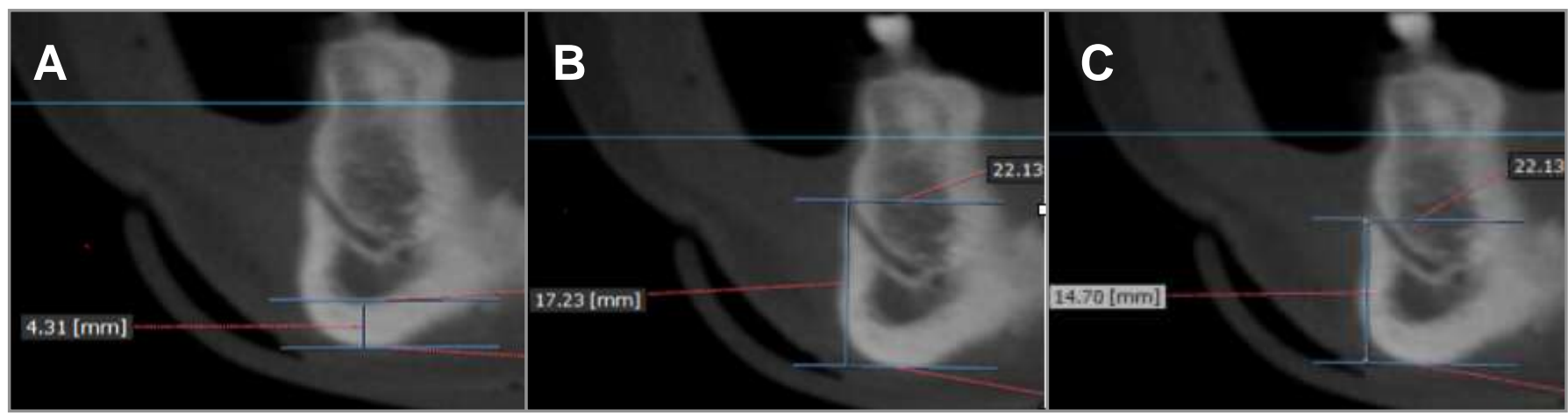

Own authorship.

The data were submitted to exploratory data analysis by means of summary measures (mean, standard deviation, minimum, median, maximum, frequency and percentage) and construction of graphs.

The groups were compared using the Kruskal-Wallis test followed by Dunn's multiple comparison test in relation to the numerical indices and through Fisher's exact test in relation to the categorical index. Spearman's coefficient was used to assess the correlation between numerical indices. The relationship between numerical indices and MI was assessed using the Kruskal-Wallis test followed by the Dunn test. Non-parametric methods were used in the analyses, as the indices were not normally distributed. The significance level considered was $5 \%$. 


\section{Results}

The sample consisted of 147 tomographic exams, 27 (18.4\%) of men aged between 65 and 75 years (group A) and $81.6 \%$ of women between the age group of 45 to 75 years. The 120 exams of the women were distributed according to the age group: group B1- from 45 to 55 years old (27.2\%), group B2 - from 56 to 65 years old (27.7\%) and group B3 - from 66 to 75 years $(27.2 \%)$.

Regarding the degree of resorption of the lower cortex of the base of the mandible (CTCI), 20 (13.6\%) were classified as $\mathrm{C} 1,117(79.6 \%)$ as $\mathrm{C} 2$ and $10(6.8 \%)$ as $\mathrm{C} 3$ (Figure 3).

Figure 3. Distribution of the absolute (n) and relative (\%) frequencies of the CTCI in the total group.

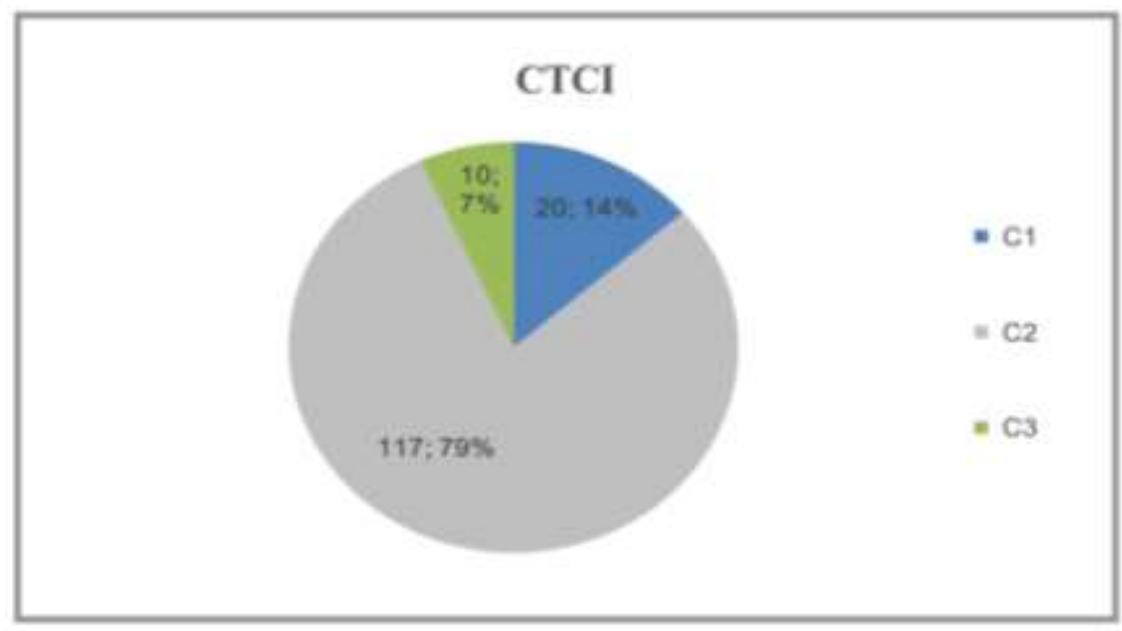

Legend: C1:Normal; C2: Osteopenia; C3: Osteoporosis. Own authorship.

Table 1 shows the descriptive measures of the radiographic parameters and the numerical indexes formed with them, in addition to the p-value of the Kruskal-Wallis test that compares the groups for these variables. Significant differences were observed between groups for the three parameters studied (p-value $<0.05$ ), the following results were observed (Dunn test):

a) MI: Group B3 had a lower measurement (significantly lower mean) than groups A, B1 and B2;

b) MCTI-L: Group B3 presented a smaller measure than groups B1 and B2; group A presented a smaller measure than group B2;

c) MCTI-U: Group B3 presented a smaller measure than groups B1 and B2; group A presented a smaller measure than group B2. 
Table 1. Measures of position and dispersion of radiographic measurements in $\mathrm{mm}$ and indices by group and result of the comparison between groups.

\begin{tabular}{ccccccccc}
\hline Index & Group & $\mathbf{N}$ & Mean & $\begin{array}{c}\text { Standard } \\
\text { deviation }\end{array}$ & Minimum & Median & Maximum & p-value \\
\hline \multirow{2}{*}{ MI } & A & 27 & 3,92 & 0,91 & 2,50 & 3,70 & 6,12 & \\
& B1 & 40 & 3,75 & 0,72 & 2,50 & 3,79 & 6,10 & $<0,0001$ \\
& B2 & 40 & 4,02 & 0,89 & 2,06 & 3,89 & 6,40 & \\
& B3 & 40 & 3,19 & 0,77 & 1,93 & 2,99 & 5,10 & \\
\hline \multirow{2}{*}{ MCTI-L } & A & 27 & 0,27 & 0,06 & 0,19 & 0,27 & 0,42 & \\
& B1 & 40 & 0,30 & 0,07 & 0,18 & 0,30 & 0,52 & $<0,0001$ \\
& B2 & 40 & 0,31 & 0,08 & 0,15 & 0,30 & 0,48 & \\
\hline \multirow{2}{*}{ MCTI-U } & B3 & 40 & 0,25 & 0,06 & 0,14 & 0,24 & 0,38 & \\
& A & 27 & 0,23 & 0,06 & 0,14 & 0,22 & 0,39 & \\
& B1 & 40 & 0,25 & 0,06 & 0,15 & 0,24 & 0,47 & 0,0001 \\
& B2 & 40 & 0,26 & 0,07 & 0,14 & 0,26 & 0,47 & \\
\hline
\end{tabular}

Own authorship.

Figure 4 show the boxplots of the parameters evaluated by group. These figures are a graphical representation of Table 1, indicating the measures of position and variation of the parameters. The box of the boxplots concentrates $50 \%$ of the data, with $25 \%$ of the ordered data being below the bottom line of the box (first quartile), $50 \%$ are below the line dividing the box (median) and 75\% are below the top line of the box (third quartile). The diamond inside the box indicates the mean and the vertical lines that go down and up from the box indicate the expected variation for the data set. 
Figure 4. Boxplots of the parameters evaluated by group: MI (A), MCTI-L (B), MCTI-U (C)

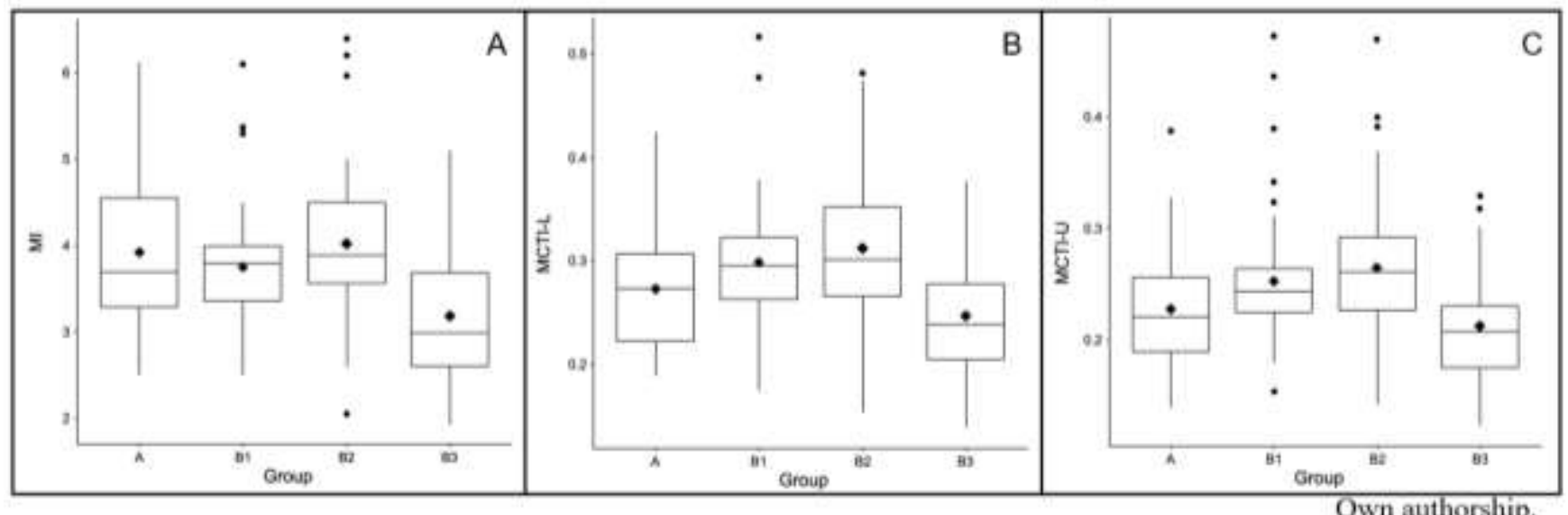

Table 2 analyzes the CTCI list by group. It is observed that groups A, B1, B2 and B3 have similar proportions to the CTCI of type C2.

Table 2. Distribution of frequency as a percentage of CTCI by group.

\begin{tabular}{ccccccc}
\hline & & $\mathbf{C 1}$ & \multicolumn{3}{c}{$\mathbf{C 2}$} & \multicolumn{3}{c}{ C3 } \\
\cline { 2 - 7 } CTCI & $\mathbf{N}$ & $\mathbf{\%}$ & $\mathbf{N}$ & $\boldsymbol{\%}$ & $\mathbf{N}$ & $\%$ \\
\hline A & 5 & 18,5 & 21 & 77,7 & 1 & 3,7 \\
\hline B1 & 11 & 27,5 & 28 & 70 & 1 & 2,5 \\
\hline B2 & 4 & 10 & 34 & 85 & 2 & 5 \\
\hline B3 & 0 & 0,0 & 34 & 85 & 6 & 15 \\
\hline
\end{tabular}

Own authorship.

The Kruskal-Wallis test was also used to assess the relationship between radiometric parameters and CTCI. Table 3 shows the descriptive measures of these parameters by CTCI. Significant differences were observed between the categories for MI (p-value <0.0001) (Figure 5A), MCTI-L (p-value = 0.0001) (Figure 5B) and MCTI-U (p-value <0.0001) (Figure 5C). In these three parameters, the value in category $\mathrm{C} 3$ is lower than in categories $\mathrm{C} 1$ and $\mathrm{C} 2$, with no significant difference between categories $\mathrm{C} 1$ and $\mathrm{C} 2$. 
Research, Society and Development, v. 10, n. 10, e191101016730, 2021

(CC BY 4.0) | ISSN 2525-3409 | DOI: http://dx.doi.org/10.33448/rsd-v10i10.16730

Table 3. Measures of position and dispersion of indices by CTCI and result of the comparison between CTCI categories.

\begin{tabular}{|c|c|c|c|c|c|c|c|c|}
\hline Index & CTCI & $\mathbf{N}$ & Mean & $\begin{array}{l}\text { Standard } \\
\text { deviation }\end{array}$ & Minimum & Median & Maximum & p-value \\
\hline \multirow{3}{*}{ MI } & $\mathrm{C} 1$ & 20 & 3,59 & 0,64 & 2,50 & 3,52 & 5,37 & \multirow{3}{*}{$<0,0001$} \\
\hline & $\mathrm{C} 2$ & 117 & 3,82 & 0,87 & 1,93 & 3,80 & 6,40 & \\
\hline & $\mathrm{C} 3$ & 10 & 2,60 & 0,44 & 2,06 & 2,55 & 3,50 & \\
\hline \multirow{3}{*}{ MCTI-L } & $\mathrm{C} 1$ & 20 & 0,26 & 0,05 & 0,18 & 0,26 & 0,36 & \multirow{3}{*}{0,0001} \\
\hline & $\mathrm{C} 2$ & 117 & 0,29 & 0,07 & 0,14 & 0,29 & 0,52 & \\
\hline & $\mathrm{C} 3$ & 10 & 0,21 & 0,03 & 0,15 & 0,20 & 0,27 & \\
\hline \multirow{3}{*}{ MCTI-U } & $\mathrm{C} 1$ & 20 & 0,22 & 0,04 & 0,14 & 0,22 & 0,31 & \multirow{3}{*}{$<0,0001$} \\
\hline & $\mathrm{C} 2$ & 117 & 0,25 & 0,06 & 0,12 & 0,24 & 0,47 & \\
\hline & $\mathrm{C} 3$ & 10 & 0,17 & 0,03 & 0,14 & 0,17 & 0,23 & \\
\hline
\end{tabular}

Own authorship.

Figure 5. Boxplots of the parameters evaluated by CTCI: MI (A), MCTI-L (B), MCTI-U (C).

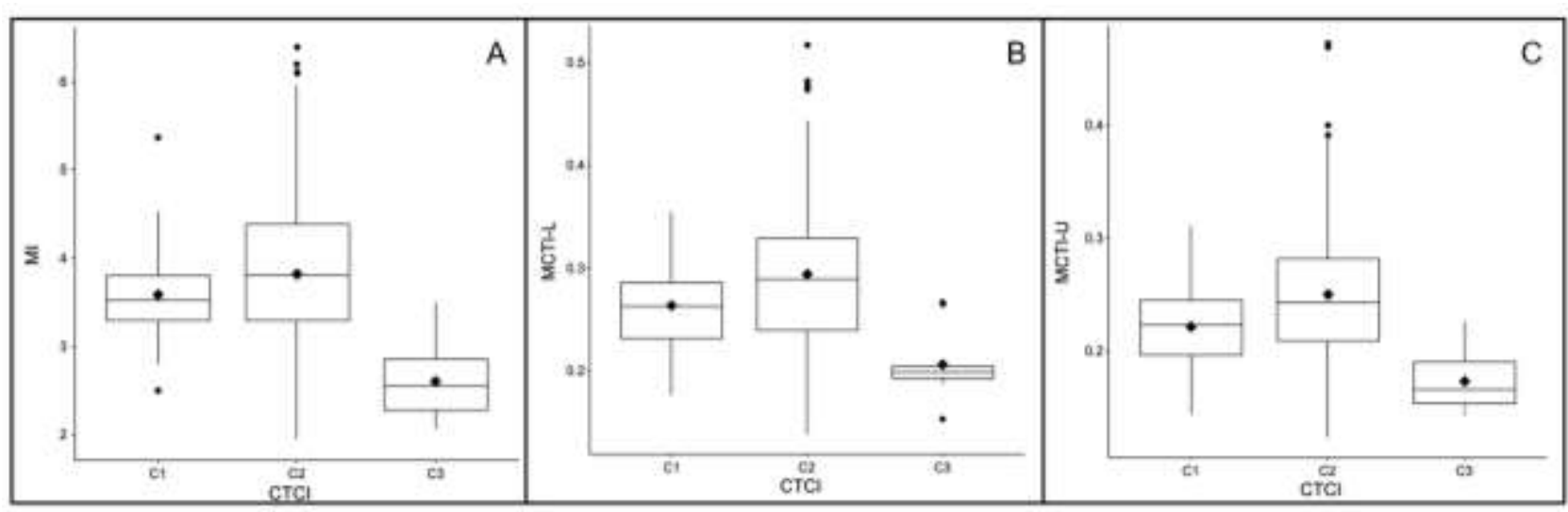

Own authorship.

Spearman's correlation coefficient was used to assess the correlation between the indices. This coefficient ( $\rho)$ can vary from -1 (indicating a strong negative correlation between the two variables) to 1 (indicating a strong positive correlation between the two variables). When $\rho$ is close to 0 , it is concluded that there is no linear correlation between the two variables. Figures 16, 17 and 18 show that the indices are highly correlated with each other, the same effect observed by $\rho$, all close to 1 . 
Figure 6. Spearman's correlation between the indices: MCTI-L vs MI (A), MCTI-U vs MI (B), MCTI-L vs MCTI-U (C).

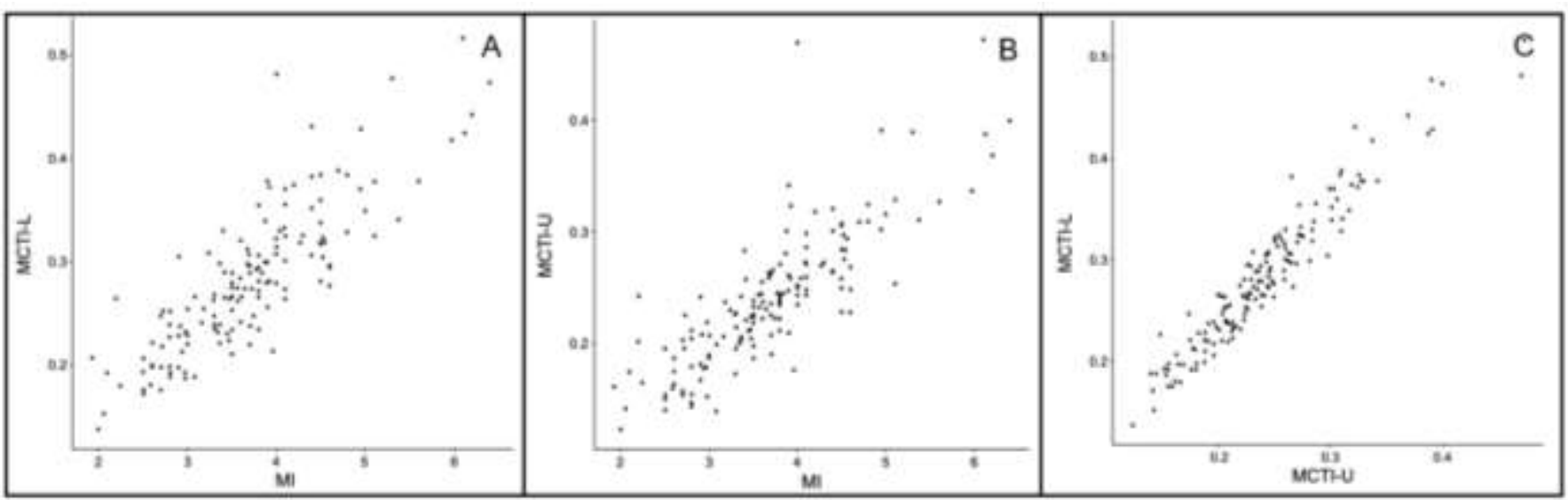

Legend:

- MCTI-L vs MI: $\rho=0,848$-valor $<0,0001$

Own authorship.

- MCTI-U vs MI: $\rho=0,866$ p-valor $<0,0001$

- MCTI-U vs MCTI-L: $\rho=0.957$ p-valor $<0.0001$

\section{Discussion}

Patients are constantly in contact with dental surgeons for dental treatment. Imaging exams, such as CBCT and radiographs are requested daily to complement the oral diagnosis. Thus, the opportunity for dental professionals to collaborate in identifying changes in the cortical and bone trabeculate patterns is necessary. In line with the work of Guerra et al. (2017), Goyushov, Dursun \& Tözüm (2020), Mizukuchi et al. (2020) and Tanaka et al. 2020, the results of this work reveal that these complementary exam instruments are significantly relevant for use in the diagnosis of bone pathologies. Emphasizing the importance of the study for clinical practice.

Several studies compare men and women of different age groups, morphometric indices and tomographic examinations (Goyushov, Dursun \& Tözüm, 2020). To understand the influence of sex on bone morphometry, the present study applied morphometric indices in tomographic examinations of men and women, among women of different age groups, and correlated them to verify for differences in bone structure.

In panoramic images, a mandibular cortex with a width below $3 \mathrm{~mm}$ in the region of the mental foramen may be a threshold value to predict low bone mineral density (Kim et al., 2016; Singh et al., 2016). Based on studies of panoramic images, when relating the MI measurement in CBCT with the different groups, the B3 group, with 40 women and older age (65 to 75 years), presented an average of $3.19 \mathrm{~mm}$, which corroborates with the studies by Kim et al. (2016) and Singh et al. (2016). The study carried out by Brasileiro et al. (2017), with 60 women, found mean MI values of $2.93 \mathrm{~mm}$ in groups of women with osteoporosis in the age group between 52 and 80 years.

Regarding the prevalence data described in the literature, it can be observed that the difference in osteoporosis between genders occurs between $50 \%$ in men and $80 \%$ in women, considering people over 65 years of age. Postmenopausal osteoporosis is the most common form of osteoporosis in women, while secondary and senile forms prevail in men (De Martinis et al., 2020).

According to Alswat (2017), gradual bone loss is common with aging from the age of years, however women tend to have an earlier onset and a faster rate of bone loss compared to men. The decrease in hormone production, especially estrogen, favors the development of pathology, since it has a bone anti-resorptive characteristic (Aziziyeh et al., 2019; Goyushov, Dursun \& Tözüm, 2020). Our results demonstrate the distribution of absolute (n) and relative (\%) frequencies of CTCI in the 
total group in which 117 (79\%) presented osteopenia, women over 65 years (B3) presented 100\% osteopenia or osteoporosis, while men over 65 have a higher rate of osteopenia $77.7 \%(\mathrm{C} 2)$ and $3.7 \%(\mathrm{C} 3)$, totaling $81.4 \%$; revealing that women progress to osteopenia or osteoporosis with age.

Taguchi et al. (2021) report that osteoporosis in women is accentuated for a period of 5 to 10 years after menopause. Afterwards this period, the rate of bone loss gradually decreases. In this study, the MCTI-L and the MCTI-U in group B3 had significantly lower measures, with a mean of 0.25 and 0.21 respectively, than groups B1 (0.30 and 0.25$)$ and B2 (0.31 and 0.26). Group A presented smaller measures, mean of 0.27 MCTI-L and 0.23 MCTI-U, than group B2, mean of 0.31 and 0.26 respectively. Brasileiro et al. (2017) reported MCTI-L and MCTI-U values of 0.24 (0.69 standard deviation) and 0.18 (0.56 standard deviation) respectively, in patients diagnosed with osteoporosis. Indicating that conditions such as post-menopause in women and age in men and women are indicative of an adjuvant tool for referring patients at risk of osteoporosis for densitometric analysis.

The Mandibular Cortical Index recommended by Klemetti, Kolmakov \& Kröger (1994) in panoramic radiographs is also evaluated in the CBCT as Computed Tomography Cortical Index (CTCI). Koh \& Kim (2011), Haas et al. (2016) and Mostafa, Arnout \& Abo El-Fotouh (2016) suggest that CTCI can be used to detect low bone mineral density. Despite the limitation numerical discrepancy between men and women, and limited applicability of the findings, the study shows that there are significant differences in the tested indices (MI, MCTI-L and MCTI-U), and that there is a high correlation between the different quantitative morphometric indices used in CBCT.

\section{Conclusion}

The study suggests that there are differences in the bone structure of men and women and between women of different age groups. Quantitative indices are highly correlated and can be a useful tool in detecting patients with low bone mineral density for later referral to bone densitometry and specialized medical treatment. The qualitative CTCI index is valid when used in conjunction with the other quantitative indices.

\section{References}

Adler R. A. (2014). Osteoporosis in men: a review. Bone research, 2, 14001. https://doi.org/10.1038/boneres.2014.1

Alonso, M. B., Vasconcelos, T. V., Lopes, L. J., Watanabe, P. C., \& Freitas, D. Q. (2016). Validation of cone-beam computed tomography as a predictor of osteoporosis using the Klemetti classification. Brazilian oral research, 30(1), S1806-83242016000100263. https://doi.org/10.1590/1807-3107BOR2016.vol30.0073

Alswat K. A. (2017). Gender Disparities in Osteoporosis. Journal of clinical medicine research, 9(5), 382-387. https://doi.org/10.14740/jocmr2970w

Aziziyeh, R., Amin, M., Habib, M., Garcia Perlaza, J., Szafranski, K., McTavish, R. K., Disher, T., Lüdke, A., \& Cameron, C. (2019). The burden of osteoporosis in four Latin American countries: Brazil, Mexico, Colombia, and Argentina. Journal of medical economics, 22(7), 638-644. https://doi.org/10.1080/13696998.2019.1590843

Brasileiro, C. B., Chalub, L., Abreu, M., Barreiros, I. D., Amaral, T., Kakehasi, A. M., \& Mesquita, R. A. (2017). Use of cone beam computed tomography in identifying postmenopausal women with osteoporosis. Archives of osteoporosis, 12(1), 26. https://doi.org/10.1007/s11657-017-0314-7

Corazza, P. F. L., Baeder, F. M., Silva, D. F., Albuquerque, A. C. L. de, Silva, J. V. L., Junqueira, J. L. C., \& Panzarella, F. K. (2020). Accuracy assessment of different CBCT acquisition protocols used in rapid prototyping models. Research, Society and Development, 9(11), e2649119842. https://doi.org/10.33448/rsd-v9i11.9842

De Martinis, M., Sirufo, M. M., Polsinelli, M., Placidi, G., Di Silvestre, D., \& Ginaldi, L. (2020). Gender Differences in Osteoporosis: A Single-Center Observational Study. The world journal of men's health, 10.5534/wjmh.200099. Advance online publication. https://doi.org/10.5534/wjmh.200099

Geibel, M. A., Löffler, F., \& Kildal, D. (2016). Osteoporoseerkennung mittels digitaler Volumentomographie [Osteoporosis detection using cone-beam computed tomography]. Der Orthopade, 45(12), 1066-1071. https://doi.org/10.1007/s00132-016-3340-z

Goyushov, S., Dursun, E., \& Tözüm, T. F. (2020). Mandibular cortical indices and their relation to gender and age in the cone-beam computed tomography. Dento maxillo facial radiology, 49(3), 20190210. https://doi.org/10.1259/dmfr.20190210 
Guerra, E., Almeida, F. T., Bezerra, F. V., Figueiredo, P., Silva, M., De Luca Canto, G., Pachêco-Pereira, C., \& Leite, A. F. (2017). Capability of CBCT to identify patients with low bone mineral density: a systematic review. Dento maxillo facial radiology, 46(8), 20160475. https://doi.org/10.1259/dmfr.20160475

Güngör, E., Yildirim, D., \& Çevik, R. (2016). Evaluation of osteoporosis in jaw bones using cone beam CT and dual-energy X-ray absorptiometry. Journal of oral science, 58(2), 185-194. https://doi.org/10.2334/josnusd.15-0609

Haas, L. F., Dutra, K., Porporatti, A. L., Mezzomo, L. A., De Luca Canto, G., Flores-Mir, C., \& Corrêa, M. (2016). Anatomical variations of mandibular canal detected by panoramic radiography and CT: a systematic review and meta-analysis. Dento maxillo facial radiology, 45(2), 20150310. https://doi.org/10.1259/dmfr.20150310

Ito M. (2011). Recent progress in bone imaging for osteoporosis research. Journal of bone and mineral metabolism, 29(2), 131-140. https://doi.org/10.1007/s00774-010-0258-0

Kim, O. S., Shin, M. H., Song, I. H., Lim, I. G., Yoon, S. J., Kim, O. J., Lee, Y. H., Kim, Y. J., \& Chung, H. J. (2016). Digital panoramic radiographs are useful for diagnosis of osteoporosis in Korean postmenopausal women. Gerodontology, 33(2), 185-192. https://doi.org/10.1111/ger.12134

Koh, K. J., \& Kim, K. A. (2011). Utility of the computed tomography indices on cone beam computed tomography images in the diagnosis of osteoporosis in women. Imaging science in dentistry, 41(3), 101-106. https://doi.org/10.5624/isd.2011.41.3.101

Klemetti, E., Kolmakov, S., \& Kröger, H. (1994). Pantomography in assessment of the osteoporosis risk group. Scandinavian journal of dental research, 102(1), 68-72. https://doi.org/10.1111/j.1600-0722.1994.tb01156.x

Marques, L. M., Costa, A. L. F., Baeder, F. M., Corazza, P. F. L., Silva, D. F., Albuquerque, A. C. L. de, Junqueira, J. L. C., \& Panzarella, F. K. (2021). Digital image filters are not necessarily related to improvement in diagnostic of degenerative bone changes in the temporomandibular joint on cone beam computed tomography . Research, Society and Development, 10(4), e44010414296. https://doi.org/10.33448/rsd-v10i4.14296

Mizukuchi, T., Naitoh, M., Hishikawa, T., Nishida, S., Mitani, A., Ariji, E., \& Koyama, S. (2020). Automatic measurement of mandibular cortical bone width on cone-beam computed tomography images. Oral radiology, 10.1007/s11282-020-00469-4. Advance online publication. https://doi.org/10.1007/s11282-020$00469-4$

Mostafa, R. A., Arnout, E. A., \& Abo El-Fotouh, M. M. (2016). Feasibility of cone beam computed tomography radiomorphometric analysis and fractal dimension in assessment of postmenopausal osteoporosis in correlation with dual X-ray absorptiometry. Dento maxillo facial radiology, 45(7), 20160212. https://doi.org/10.1259/dmfr.20160212

Pêgo, M. de M. F., Corazza, P. F. L., Baeder, F. M., Silva, D.F., Albuquerque, A. C. L. de, Junqueira, J. L. C., \& Panzarella, F. K. (2021). Development of the teeth, cervical vertebrae, hand and wrist combined for the estimation of the biological age. Research, Society and Development, 10(3), e8510312948. https://doi.org/10.33448/rsd-v10i3.12948

Singh, S. V., Aggarwal, H., Gupta, V., Kumar, P., \& Tripathi, A. (2016). Measurements in Mandibular Pantomographic X-rays and Relation to Skeletal Mineral Densitometric Values. Journal of clinical densitometry : the official journal of the International Society for Clinical Densitometry, 19(2), 255-261. https://doi.org/10.1016/j.jocd.2015.03.004

Shokri, A., Ghanbari, M., Maleki, F. H., Ramezani, L., Amini, P., \& Tapak, L. (2019). Relationship of gray values in cone beam computed tomography and bone mineral density obtained by dual energy X-ray absorptiometry. Oral surgery, oral medicine, oral pathology and oral radiology, 128(3), 319-331. https://doi.org/10.1016/j.oooo.2019.04.017

Syed, F. A., \& Ng, A. C. (2010). The pathophysiology of the aging skeleton. Current osteoporosis reports, 8(4), 235-240. https://doi.org/10.1007/s11914-010$0035-\mathrm{y}$

Taguchi, A., Tanaka, R., Kakimoto, N., Morimoto, Y., Arai, Y., Hayashi, T., Kurabayashi, T., Katsumata, A., Asaumi, J., \& Japanese Society for Oral and Maxillofacial Radiology (2021). Clinical guidelines for the application of panoramic radiographs in screening for osteoporosis. Oral radiology, 37(2), 189208. https://doi.org/10.1007/s11282-021-00518-6

Tanaka, R., Tanaka, T., Yeung, A., Taguchi, A., Katsumata, A., \& Bornstein, M. M. (2020). Mandibular Radiomorphometric Indices and Tooth Loss as Predictors for the Risk of Osteoporosis using Panoramic Radiographs. Oral health \& preventive dentistry, 18(1), 773-782. https://doi.org/10.3290/j.ohpd.a45081

Yousefi, F., Shokri, A., Farhadian, M., Vafaei, F., \& Forutan, F. (2021). Accuracy of maxillofacial prototypes fabricated by different 3-dimensional printing technologies using multi-slice and cone-beam computed tomography. Imaging science in dentistry, 51(1), 41-47. https://doi.org/10.5624/isd.20200175 